\title{
Influence of sowing time and weather factors on seasonal dynamics of aphids in three wheat growing zones of India
}

\author{
SUBHASH KATARE ${ }^{1}$, POONAM JASROTIA ${ }^{1 *}$, S.D. PATIL ${ }^{2}$, MD. WASIM REZA ${ }^{3}$ \\ and M.S. SAHARAN ${ }^{4}$ \\ ${ }^{1}$ Indian Institute of Wheat and Barley Research, Karnal, India \\ ${ }^{2}$ Department of Entomology, Agricultural Research Station, Niphad, India \\ ${ }^{3}$ Regional Research Sub-station (Terai Zone) Kharibari, UBKV, Darjeeling, W.B, India \\ ${ }^{4}$ Division of Plant Pathology, IARI, New Delhi, India \\ *Email:poonamjasrotia@gmail.com
}

\begin{abstract}
A study was conducted to evaluate the relative population abundance of foliar aphid on wheat at three locations (Karnal, Niphad and Kharibari) sown on three different dates during rabi season of 201314 and 2014-15.The highest seasonal average population of aphids of 44.5 and 61.5 aphids per tiller at Karnal and Niphad, respectively were recorded on the crop sown during Ist fortnight of November and the lowest seasonal average population of 4.3 and 2.7 aphids per tillerat Karnal and Niphad, respectively were recorded on crop sown during $2^{\text {nd }}$ fortnight of December. The studies indicated that early planted crop during November month provided the congenial weather conditions for aphid proliferation during crop growth period.
\end{abstract}

Key Words: Aphid development, planting time, wheat, insect management.

Arthropod pests are one of the major constraints to agricultural production in India. A large number of insect and mite pests attack crops during all stages of growth from seedling to storage. Wheat crop is host of more than 100 species of arthropods that reduce grain quality and yield and increase production costs (Hatchett et al., 1987). Among the different insect-pest attacking wheat crop, cereal aphids are considered to be major pests of wheat. The pest can cause yield losses either directly (3-21\%) by sucking the sap of the plants or indirectly (20-80\%) by transmitting viral and fungal diseases (Singh et al., 2003). Economic threshold level for wheat aphids was established as five aphids/earhead or ten aphids/ tiller during vegetative stage, which being a low population level reflected their economic importance (Singh et al., 2003).

Aphid population under wheat agro-ecosystem is regulated by number of biotic and abiotic factors (Asin and Pons, 2001; Aheer et al., 2007). Amongst the abioitc factors temperature plays a major role in regulating aphid population (Brabec et al., 2014; Bapuji rao et al., 2012). Under changing climate scenario, changes in agronomic practices for instance change in planting time, use of resistant cultivars, optimum water and nutrient use will play a vital role (Mondal et al., 2013). Thus, to determine the effect of date of sowing and weather factors on the incidence of foliar aphids on wheat in three different wheat growing zones of India, the present study was undertaken.

\section{MATERIALS AND METHODS}

The study was carried out under All India Coordinated Wheat and Barley Improvement Programme (AICW \& BIP). The experimental trial was conducted during rabi seasons of 2013-14 and 2014-15 at its three centres of AICW programme viz., Indian Institute of Wheat and Barley Research, Karnal, Haryana $\left(29^{\circ} 41^{\prime} \mathrm{N}, 76^{\circ} 59^{\prime} \mathrm{E}\right.$ and $250 \mathrm{~m}$ above mean sea level), Agricultural Research Station, Niphad, Maharashtra $\left(20^{\circ} .6^{\prime} \mathrm{N}, 74^{\circ} 07^{\prime} \mathrm{E}\right.$ and $244 \mathrm{~m}$ above mean sea level) and Regional Research Sub-station (Terai Zone) Kharibari, UBKV, Darjeeling, West Bengal $\left(26.55^{\circ} \mathrm{N}, 88.19^{\circ}\right.$ $\mathrm{E}$ and $2050 \mathrm{~m}$ above mean sea level).

The wheat crop was sown at four different dates viz., $1^{\text {st }}$ November ( ${ }^{\text {st }}$ fortnight $), 16^{\text {th }}$ November ( $2^{\text {nd }}$ fortnight $), 1^{\text {st }}$ December ( $\mathrm{I}^{\text {st }}$ fortnight $)$ and $16^{\text {th }}$ December ( $2^{\text {nd }}$ fortnight $)$ during each year at two locations i.e. Karnal and Niphad. At third location,Kharibari, West Bengal,the crop was sown only on three dates i.e. $1^{\text {st }}\left(I^{\text {st }}\right.$ fortnight $), 16^{\text {th }}$ December $\left(2^{\text {nd }}\right.$ fortnight) and $15^{\text {th }}$ January ( $\mathrm{I}^{\text {st }}$ fortnight $)$ of 2014-15 season. The wheat varieties used in this experiment were HD-2967, 

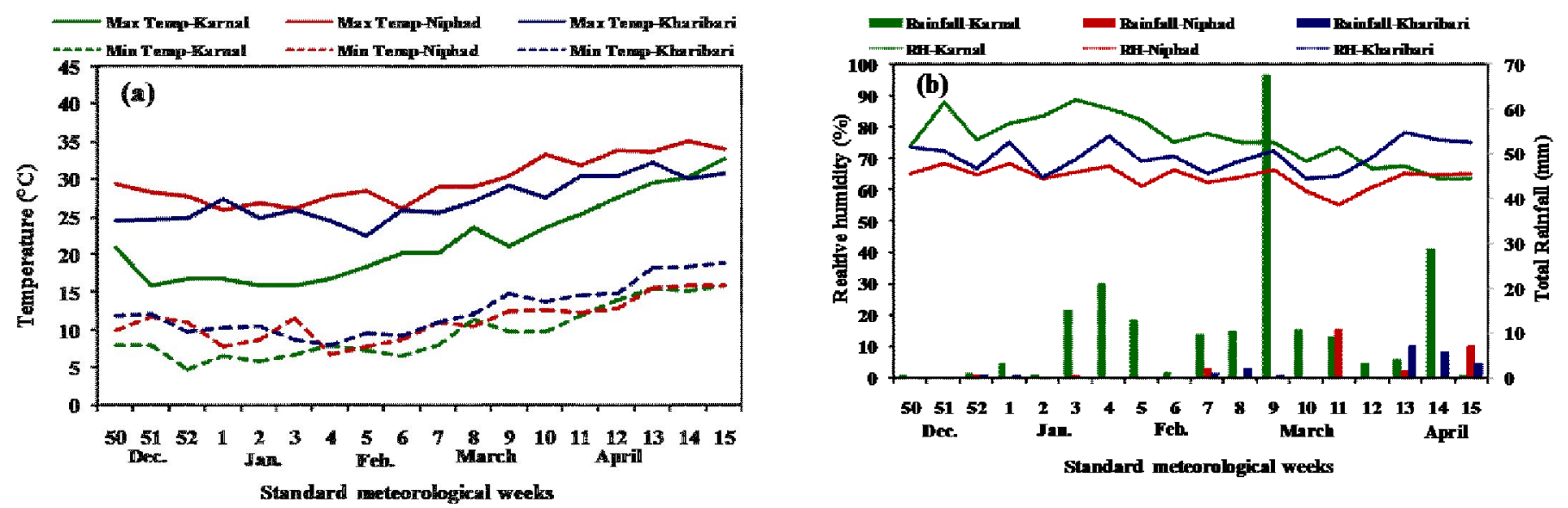

Fig. 1: Weather parameters at three locations during 2013-2014 and 2014- 2015 (Pooled data except location Kharibari)

NIAW-917 and Sonalika for Karnal, Niphad and Kharibari, respectively.Plant to plant and row to-row distance was kept as $10 \mathrm{~cm}$ and $25 \mathrm{~cm}$, respectively. The experiment was laid out in randomized block design with four replications in plots of size $5 \mathrm{~m} \times 4 \mathrm{~m}$. The crop was maintained by following recommended package of practices.

The population of aphid was recorded visually by counting number of aphids present on each plant. Ten plants were randomly selected and tagged in each plot for aphid population records. The number of aphids present per plant on these ten randomly selected plants was recorded on weekly basis. Aphid population data from ten plants in each plot were averaged and considered as one replicate for analysis. The data on aphid density were first normalized using square root transformation. An analysis of variance (ANOVA) was performed to determine the effect of location and date of sowing of wheat on aphid population. Since there was no significant difference $(p=0.05)$ in pest population recorded at each location from plots of same planting time during both years, the data of aphid population for both years were pooled for statistical analysis. The weatherparameters viz., maximum and minimum temperatures $\left({ }^{\circ} \mathrm{C}\right)$, morning and evening relative humidity $(\%)$ and amount of rainfall $(\mathrm{mm})$ were obtained from respective agrometeorological observatory. Average values of the weather parameters, based on 10 days period preceding aphid population counts, were used in computing correlation coefficients. All tests were performed at the 0.05 significance level.

\section{RESULTS AND DISCUSSION}

The maximum and minimum average temperatures for two seasons at Karnal varied from 15.8 to $32.7^{\circ} \mathrm{C}$ and 5.9 to $15.9^{\circ} \mathrm{C}$,respectively. Similarly, at Niphad the maximum and minimum average temperatures for two seasons were in the range of 26.0 to $35.1{ }^{\circ} \mathrm{C}$ and 7.9 to $15.9^{\circ} \mathrm{C}$, respectively. The maximum and minimum average temperatures at Kharibari location were in the range of 22.6 to $32.2^{\circ} \mathrm{C}$ and 9.6 to $18.3^{\circ} \mathrm{C}$ (Fig. 1a). The percent average humidity for two seasons at Karnal ranged 63 to 88 per cent while for Niphad and Kharibari, it was 55 to 68 per cent and 63 to 78 per cent, respectively. The highest rainfall i.e. $67.6 \mathrm{~mm}$ was recorded at Karnal during $9^{\text {th }}$ standard meteorological week while it was lowest $7.11 \mathrm{~mm}$ at Kharibari during $13^{\text {th }}$ standard meteorological week (Fig. 1b).

At Karnal location, the aphid population started appearing during $3^{\text {rd }}$ standard meteorological week on the crop which was sown during first fortnight of November. The highest peak population of 201.6 aphids per tiller was recorded on the crop sown during $\mathrm{I}^{\mathrm{It}}$ fortnight of November during $5^{\text {th }}$ standard meteorological week while lowest peak population of 21.5 aphids per tiller was recorded during $7^{\text {th }}$ standard meteorological week on crop sown during $2^{\text {nd }}$ fortnight of December (Fig. 2a).

At Niphad, highest peak population of 337.4 aphids per tiller was recordedduring $2^{\text {nd }}$ standard meteorological week on the crop sown during ${ }^{\text {It }}$ fortnight of November while lowest peak population of 35.4 aphids per tiller was recorded during $4^{\text {th }}$ standard meteorological weekon crop sown during $2^{\text {nd }}$ fortnight of December (Fig. 2a). At Kharibari, the crop sown during $2^{\text {nd }}$ fortnight of December had highest peak population of aphid (344.1 aphids per tiller) during $7^{\text {th }}$ standard meteorological week while lowest peak population i.e.186.6 aphids per tiller was recorded on crop sown during $2^{\text {nd }}$ fortnight of January (Fig. 2c).

Overall, the highest average population of aphids (44.5 and 61.5 aphids/tiller) throughout the season was 
Table 1: Effect of location and date of sowing on aphid population (Pooled data for 2 years).

Factors Aphid population/tiller
Actual values
$\sqrt{\mathrm{n}}+1$

\section{Locations*}

$\begin{array}{lll}\text { Karnal,Haryana } & 19.4 & 4.5 \\ \text { Niphad,Maharashtra } & 20.3 & 4.6 \\ \text { LSD }(p=0.05 \%) & & 0.9\end{array}$

\section{Date of sowing}

It fortnight of November

62.3

7.9

$\mathrm{II}^{\text {nd }}$ fortnight of November

22.9

4.8

$I^{\text {st }}$ fortnight of December

9.8

3.2

II $^{\text {nd }}$ fortnight of December

3.6

2.1

$\operatorname{LSD}(p=0.05 \%)$

$<0.001$

\section{Date of sowing $x$ Location}

$\mathrm{I}^{\mathrm{st}}$ fortnight of November

51.1

7.2

II ${ }^{\text {nd }}$ fortnight of November

22.7

4.8

$\mathrm{I}^{\text {st }}$ fortnight of December

11.3

3.5

II $^{\text {nd }}$ fortnight of December

5.2

2.4

$\operatorname{LSD}(p=0.05 \%)$ interaction $=$ Date of sowing $\mathrm{x}$ Location $=0.80$
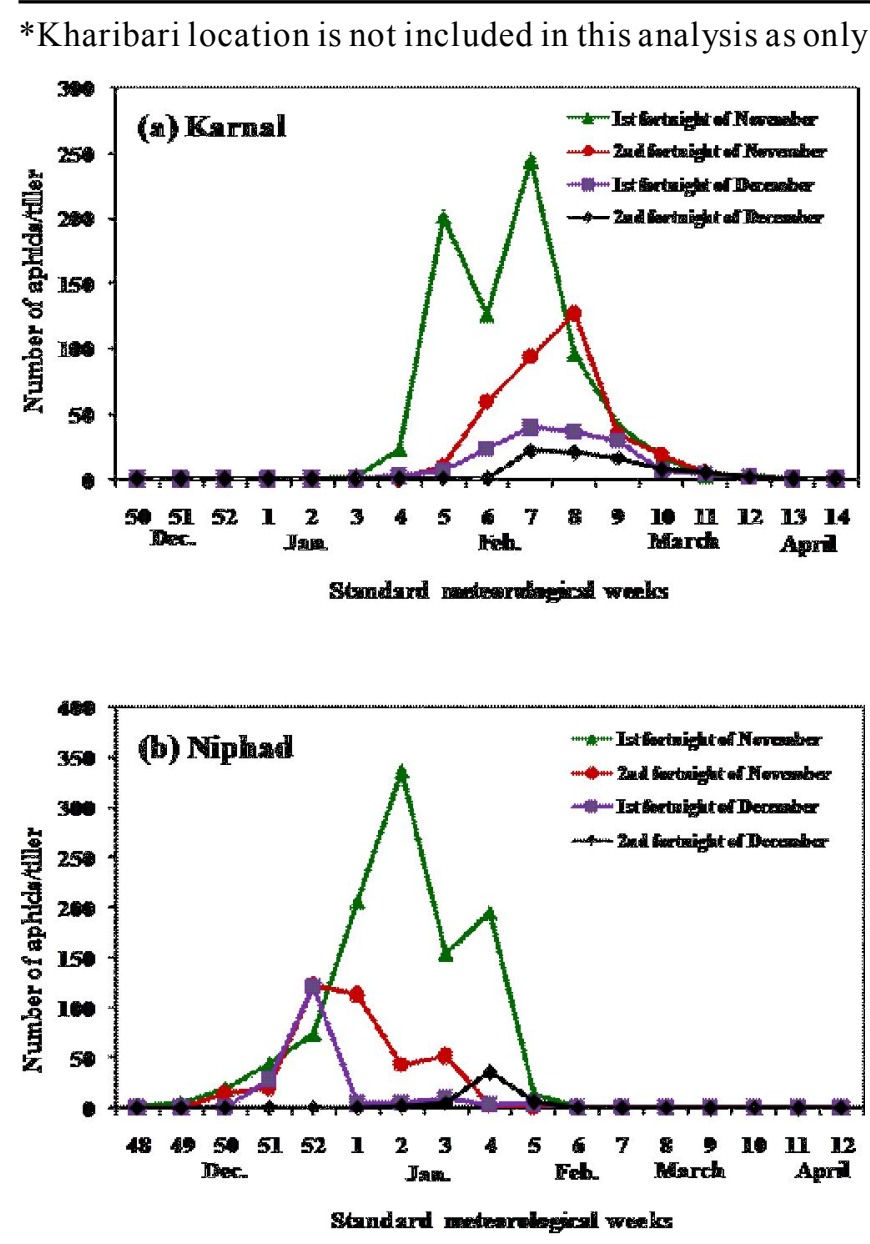

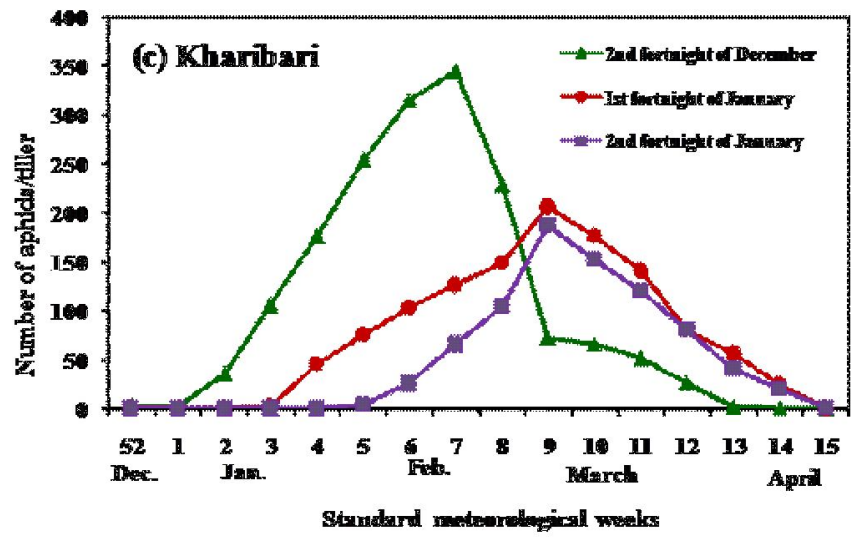

Fig. 2: Population build-up of foliar aphid (Rhopalosiphum spp.) at three locations on wheat sown at different dates during 2013-2014 and 2014- 2015 (Pooled data except location Kharibari)

recorded on the crop sown during $\mathrm{I}^{\text {st }}$ fortnight of November at Karnal and Niphad, respectively. However, the lowest average population (4.3 and 2.7 aphids/tiller) was recorded on crop sown during $2^{\text {nd }}$ fortnight of December at Karnal and Niphad, respectively. Similar trends were observed at Kharibari with average highest population of 105.0 aphids per tiller on crop sown during $2^{\text {nd }}$ fortnight of December 
Table 2: Simple linear correlation coefficients between aphid population on wheat and weather parameters during the study period

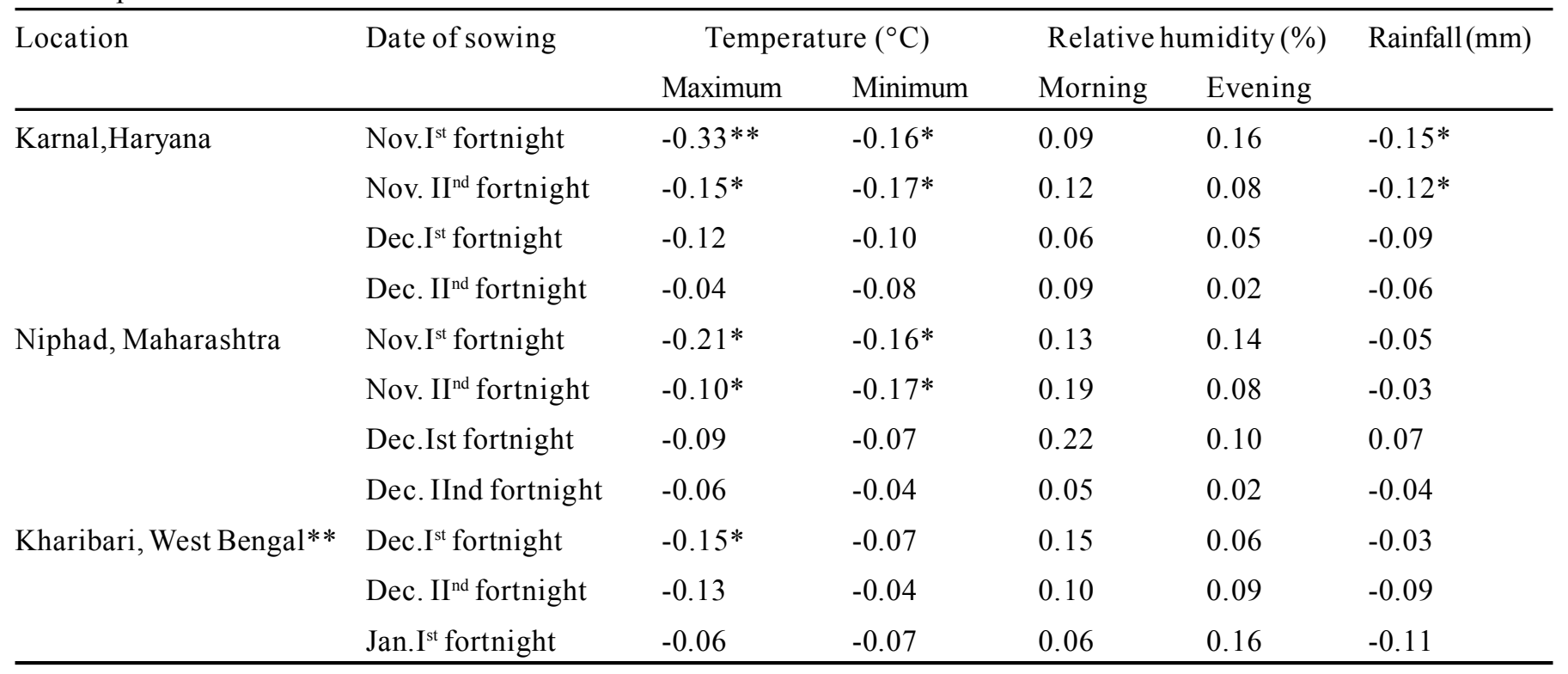

$\mathrm{N}=22$ for Karnal and Niphad locations; $\mathrm{N}=17$ for Kharibari location; * Significant at $P=0.05$ NS- Non Significant** Only 2014 15 data for Kharibari location

while lowest population of 50.0 on crop sown during $2^{\text {nd }}$ fortnight of January (Fig. 2).

Two year pooled data of Karnal and Niphad showed non significant differences in aphid population but date of sowing alone and interaction of date of sowing with location had significant effect on aphid population (Table 1). The crop sown during I $^{\text {st }}$ fortnight of November had highest number of aphids 62.3 aphids per tiller and lowest number of aphids 3.6 aphids per tiller) was recorded on crop sown during $2^{\text {nd }}$ fortnight of December.

Correlation of weather parameters with aphid population showed a significant negative correlation with maximum and minimum temperatures on November sown crop only. However,total rainfall showed a significant negative correlation with aphid population only at Karnal location on November sown crop (Table 2). The present findings are in line with the previous studies which reported that abiotic factors seriously affect the population build-up of wheat aphids (Nasir and Ahmad, 2001).Bapuji Rao et al. (2012) also reported that the mustard aphids were negatively correlated with temperature and positively correlated with relative humidity.

Our studies concluded that date of sowing significantly influenced the aphid population and early sown crop harboured higher aphid population as compared to late sown crop. Weather certainly played its role in deciding population dynamics of aphids on wheat. Amongst weather parameters, temperature and rainfall at one location showed significant role in influencing the dynamics of aphids on wheat.

\section{REFERNCES}

Aheer, G.M., Munir,M. and Ali,A. (2007).Impact of weather factors on population of wheat aphids at Mandi Bahaud-Din district. J.Agric. Res., 45:61-66

Asin, L. and Pons,X.(2001). Effect of high temperature on the growth and reproduction of corn aphids (Homopetra: Aphididae) and implication for their population dynamics on the North Eastern Iberian Peninsula. Environ. Entomol., 30:1127-34

Bapuji Rao, B., Ramarj, A. P., Chattopadhyay, C., Prasad, Y. G. and Rao, V.U.M. (2012). Predictive model for mustard aphid infestation for eastern Rajasthan. J. Agrometeorol. 14(1): 60-62.

Brabec, M., Honì, A., Pekár, S. and Martinková, Z. (2014). Population dynamics of aphids on cereals: digging in the time-series data to reveal population regulation caused by temperature. PloS one, 9(9):p.e106228.

Hatchett, J.H., Starks K.J. and Webster J.A. (1987).Insect and mite pests of wheat. In: Heyne EG(ed) Wheat and Wheat 
Improvement, pp. 625-675. Agron Monograph., 13. ASA, CSSA, and SSSA, Madison, WI(1987).

Mondal, S., Singh, R.P., Crossa, J., Huerta-Espino, J., Sharma, I.,Chatrath, R., Singh, G.P., Sohu, V.S., Mavi, G.S., Sukaru, V.S.P., Kalappanavarg, I.K., Mishra, V.K., Hussain, M., Gautam, N.R., Uddin, J.,Barma, N.C.D., Hakim, A. and Joshi,A.K. (2013).Earliness in wheat: akey to adaptation under terminal and continual high temperature stress in
South Asia. Field Crops Res., 151:19-26

Nasir, S. and Ahmad, F. (2001).Correlation between wheat aphid population and abiotic factors.Pak. Entomol, 23, 23-25

Singh, B., Deol, G.S. and Mahal, M.S. (2003).Economic threshold level for the control of cereal aphid complex on wheat.Crop Res., 26(3):497-500 